to put effective barriers between parts of the atoll, and in any case the eastern area of the south island is the most interesting part of Aldabra. Once development begins, the destruction of the ecosystem, which has been occurring very slowly ever since domestic animals and weeds were introduced by the settlers who arrived in 1888, will be accelerated, and the ecosystem as it is now-largely unaffected by manwill eventually be destroyed. In its new approach the Royal Society has stressed the great value of Aldabra as an integrated island ecosystem the study of which would give information valuable not only to biological science but also for the understanding of other ecosystems, including those of economic and social importance.

\section{New Post}

Following the discovery of natural gas, the Gas Council announced, in its annual report earlier this year, a reorientation of its research policy into two sectors, one to cover current problems and the other to investigate the full and economic use of natural gas. The council is now advertising for a distinguished scientist to direct all research activities, which means taking charge of the five research establishments and an annual expenditure of at least $£ 2.5$ million. The post is a new one and remuneration is a matter for discussion, but corresponding research posts in the National Coal Board and the Central Electricity Generating Board command salaries in the $£ 7,000$ to $£ 9,500$ range.

\section{Safe Vaccine}

A NEW method for preparing canine distemperhepatitis vaccine in established cell lines of canine kidney tissue has been developed by Dr L. Brown, director of the biological research division of Norden Laboratories Inc., Lincoln, Nebraska. Dr Brown described the method at a conference for the Division of Biologies Standards at the National Institute of Health, Bethesda, on November 6-8. The vaccinecontaining two attenuated live vaccines and called 'Enduracell D-H', has been used to vaccinate approximately one million dogs since it was first introduced in 1963.

There are several advantages in using an established cell line for vaccine production. A cell line of this nature contains only one kind of cell and every cell is genetically related: each cell therefore has the same biochemical characters, the same growth rate, the same virus susceptibility and, when infected with a virus, will respond in the same way. As a result, vaccine production is very regular; it contains a uniform virus concentration and has consistent antigenic potency. It is important to use cells for vaccine production from the same species in which the vaccine will be used. This ensures that the virus maintains its maximum ability to invade cells of a given species, resulting in maximum immunity. It also reduces the danger of foreign protein reactions.

The DK line is produced from a master seed stock and every serial of vaccine is produced at the same passage level. This development of uniformly potent and safe vaccine is to be extended to the production of rabies vaccine for dogs, cats and cattle, and Dr Brown. anticipates that it will soon be possible to prepare all vaccines in established cell lines.

\section{Parliament in Britain}

\section{Oceanography}

DR J. BRAY, Joint Parliamentary Secretary, Ministry of Technology, said that research was proceeding with the hope of increasing the range of optical detection in turbid water, and the National Research Development Corporation, in conjunction with the Ministry of Defence, had patented and was exploiting a non-optical imaging system for underwater viewing. The corporation had for some months been studying with a group of industrialists the requirements of a technologically based diving activity, and this group was now engaged in generating the necessary development work to produce a wide range of aids and equipment for submarine use. In common with the governments of other member countries of the United Nations, the Government was cooperating in a comprehensive survey of activities in marine science and technology, with a view to formulating proposals for an expanded programme of international cooperation in oceanography. (Written answer, November 7.)

\section{Biological Warfare}

The Minister of Defence for Equipment, Mr R. Mason, said that the Government's policy was to publish as much as possible of the results of microbiological research at the Porton Laboratory. Last year forty papers by the staff of the Microbiological Research Establishment were published and members of the staff gave lectures and attended national and international symposia. An annual report, in the form of abstracts of all original work published, was issued to about 300 libraries at universities, research institutions and industrial organizations, and copies were available on request. From December 1, 1967, all suitable unclassified departmental reports would be released to the National Lending Library for Science and Technology. Much of the work was helping the medical research centres. (Oral answer, November 8.) Weather

Mr. M. REes, Under-Secretary of State for Defence for the Royal Air Force, stated that over the next four years the British contribution to the World Weather Watch was expected to amount to some $£ 2 \cdot 5-£ 3$ million, or about 7 per cent of the total cost. Britain had offered to act as a Regional Meteorological Centre and a Regional Telecommunications Hub, to continue to develop its research effort, to improve surface and upper air observations and to provide free training for overseas meteorologists. In addition, he said, Britain would make substantial amounts of equipment available for use for developing countries and would make an additional annual contribution of $£ 30,000$ to the World Metcorological Organization. (Written answer, November 8.)

\section{Student Grants}

Mrs Shirley Williams, for the Department of Education and Science, said that grants to students in the current academic year would cost an estimated $£ 129$ million. $£ 9$ million of this was for postgraduate awards and the remainder for first degree courses. Mr Patrick Gordon Walker said the raising of the school leaving age to 16 in 1971-2 would cost $£ 44$ million in the first year. It was too soon to tell, he said in answer to another question, whether the $£ 0.5$ million set aside for aid to overseas students would prove adequate. (Written answer, November 9.) 